\title{
Chitosan Suppresses Antioxidant Enzyme Activities for Mitigating Salt Stress in Mungbean Varieties
}

\author{
Shuma Rani Ray ${ }^{*}$, Muhammad Javidul Haque Bhuiyan, Mohammad Anowar \\ Hossain, Sakil Mahmud, M. Tahjib-Ul-Arif \\ Department of Biochemistry and Molecular Biology, Bangladesh Agricultural University, Mymensingh-2202.
}

\begin{abstract}
An experiment was conducted to evaluate the effect of chitosan on the antioxidant enzyme activity and protein content in four Mungbean varieties (BARI Mung3, BARI Mung6, BINA Mung5 \& BINA Mung8) under salinity. Each pot having eight kilograms of soil was ready to grow three plants of each variety. The experiment was comprised with four different conditions in triplicates viz. control, saline (40mM Nacl, 25DAS), saline +chitosan (25ppm chitosan, 30DAS on saline condition) and chitosan (25ppm chitosan on control condition). Seed collections was done at $60 \mathrm{DAS}$ followed by data analysis. Protein content (using $\mathrm{H}_{2} \mathrm{SO}_{4}$, $\mathrm{CuSO}_{4}, \mathrm{~K}_{2} \mathrm{SO}_{4}$ \& selenium in Kjeldahl method), catalase (CAT), ascorbate peroxidase (APX), peroxidase (POD) (using potassium phosphate buffer, EDTA, $\mathrm{H}_{2} \mathrm{O}_{2}$, ascorbate, guaicol) were measured accordingly. Salinity enhanced antioxidant enzyme [CAT (maximum $2.47 \mathrm{mM} / \mathrm{ml}$ in BARI Mung3), POD (maximum $0.406 \mathrm{mM} / \mathrm{ml}$ in BARI Mung6) and APX (maximum 11.99mM/ml in BINA Mung8)] activities compare to control groups in all four varieties. On the other hand, the significant reduction in protein content during salt stress was drastically increased with chitosan application. However, chitosan played an outstanding stimulating role to reduce antioxidant enzyme activities by scavenging ROS (Reactive Oxygen Species). Therefore, it is suggested that chitosan could be an effective biostimulator to avoid the salinity stress by scavenging ROS.
\end{abstract}

Keywords: Salinity stress, Chitosan, Antioxidant enzymes, ROS.

\section{Introduction}

Pulses are the best dietary source of plant proteins which can play influential role to fulfil the requirements of rapidly increasing population. Mungbean [Vigna radiate (L.)] is an important short summer season pulse crop which is grown primarily for its protein rich edible seeds. Since it has ability to enhance the physical, chemical and biological soil properties, it is considered as an important component of sustainable agriculture (Yasin et al., 1998). This short duration crop requires less water than other summer crops; therefore, it can be grown in rain-fed areas (Anjum et. al. 2012). However, abiotic stresses severely reduce the productivity of almost all pulse crops including mungbean (Gao et al., 2007). As reported earlier among the most of the known pulse crops mungbean is relatively more sensitive to saline stress (Chakrabarti and Mukherji, 2003). Activities of antioxidant enzymes have been reported to increase in many crops (Mittova et al., 2002; Ashraf, 2009) including mungbean under saline stress. These enhanced activities of antioxidant enzymes (CAT, APX and POD) and non-enzymatic antioxidants (ascorbate, tocopherols and phenolic compounds) help to protect the mungbean plants from damages caused by salt-induced ROS (Yasar et al., 2008). It is now widely accepted that ROS are responsible for various stress-induced damage to macromolecules and ultimately to cellular structure (Moftah and Michel, 1987; Kandpal et al., 1981). So it is necessary to scavenge ROS for maintaining normal growth. APX (EC 1.11.1.11), CAT (EC 1.11.1.6) and POD (EC 1.11.1.7), together with low-molecular mass scavengers such as ascorbate, glutathione and proline, act as the main defense against ROS produced in various parts of plant cells (Apel and Hirt, 2004). Since the adverse effect of salinity causes remarkable loss in yield and quality of crops different techniques like salt resistant variety development, modulation of intercultural operation or application of some bio-stimulators are continuously being practiced by researchers. Application of chitosan (as a biostimulator) could be one of the methods to decrease the negative effect of abiotic stress. Chitosan is a cationic polysaccharide produced by alkaline $\mathrm{N}$-deacetylation of chitin. The beneficial effects of chitosan in enhancing tolerance of plants to biotic and abiotic stresses and its relevance to agriculture have been described earlier (Farouk et al., 2012). Antioxidant activity of chitosan has also been described (Park et al., 2004). Chitosan modulates the plant response to several abiotic stresses including salt and water stress (Ruan and Xue 2002, Dzung et al., 2011).

\section{Materials And Methods}

Experimental site and time: The experiment was conducted at the laboratory of the department of Biochemistry and Molecular Biology, Bangladesh Agricultural University, Mymensingh during the period from January to June, 2015. 
Materials: Seeds of four Mungbean varieties were collected from Bangladesh Agricultural Research Institute (BARI), Gazipur and Bangladesh Institute of Nuclear Agriculture (BINA), BAU, Mymensingh. The collected seeds were stored in refrigerator $\left(\right.$ at $\left.-4^{0} \mathrm{C}\right)$ till use for experimental purpose.

Treatments: The experiment was comprised with four individual groups for different treatments as such as: $\mathrm{T}_{0^{-}}$control condition was maintained by growing plants under natural environment only applying normal water and normal doses of fertilizers.

$\mathrm{T}_{1}-40 \mathrm{mM}$ saline condition was induced by applying $20 \mathrm{~g} \mathrm{NaCl} \mathrm{pot}^{-1}$ at $25 \mathrm{DAS}$.

$\mathrm{T}_{2^{-}}$saline+chitosan condition was induced by applying chitosan $\left(25 \mathrm{ppm}\right.$ chitosan solution pot $\left.^{-1}\right)$ in the pot containing salt after one week of salt application.

$\mathrm{T}_{3^{-}}$chitosan condition was maintained by applying chitosan $\left(25 \mathrm{ppm}\right.$ chitosan solution pot $\left.^{-1}\right)$ at 30 DAS in control condition.

Preparation of pot: Earthen pots were prepared for seed planting of mungbean varieties (BARI Mung3, BARI Mung6, BINA Mung5 and BINA Mung8). For each variety pots were prepared as triplicates. Thus total 48 (12×4) pots were filled with $8 \mathrm{~kg} \mathrm{pot}^{-1}$ soil and then 5 seeds were sown at 08 April 2015 in each pot. At 18 DAS thinning (keeping 3 plants in each pot) and fertilization (Urea $4 \mathrm{~g}$; muriate of potash $2.5 \mathrm{~g}$; \& boric acid $1.5 \mathrm{~g}$ ) were performed.

\section{Determination of enzymatic activity Extraction}

Fifty milligrams of fresh leaf sample was collected and homogenized with $3 \mathrm{ml}$ of $50 \mathrm{mM}$ potassium phosphate buffer ( $\mathrm{pH} \mathrm{8.0)}$ in a mortar and pestle. The homogenate was centrifuged at $12000 \mathrm{rpm}$ for $10 \mathrm{~min}$. The clear supernatant was used for assaying the catalase activity.

Catalase (CAT) (EC 1.11.1.6) Activity: CAT activity was measured in accordance of Aebi (1984). The assay contained $0.1 \mathrm{ml}$ of enzyme extract, $0.1 \mathrm{mM}$ phosphate buffer ( $\mathrm{pH} 7.5$ ), $0.1 \mathrm{M}$ EDTA and $0.3 \% \mathrm{H}_{2} \mathrm{O}_{2}$ and the absorbance was measured at $240 \mathrm{~nm}$. CAT activity was expressed as $\mu \mathrm{mol} \mathrm{H}_{2} \mathrm{O}_{2} \mathrm{~g}^{-1} \mathrm{~F}$.W. For the calculation of CAT activity, the extinction coefficient of $0.026 \mathrm{mM}^{-1} \mathrm{~cm}^{-1}$ was used.

Peroxidase (POD) (EC: 1.11.1.6) Activity: Peroxidase activity was assayed by the method of Kumar and Khanna (1982). Assay mixture contained $0.6 \mathrm{ml}$ of $50 \mathrm{mM}$ potassium phosphate buffer $(\mathrm{pH} 8.0), 0.1 \mathrm{ml}$ of EDTA, $0.1 \mathrm{ml}$ of $\mathrm{H}_{2} \mathrm{O}_{2}$ and $0.1 \mathrm{ml}$ of Guaiacol. Reaction was started by adding $0.1 \mathrm{ml}$ of enzyme extract and changes in absorbance were recorded immediately at $470 \mathrm{~nm}$ with 30 seconds interval for two minutes. The activity of peroxidase was calculated from the increase in absorbance per minute when the extinction coefficient of $\mathrm{H}_{2} \mathrm{O}_{2}$ was $40 \mathrm{M}^{-1} \mathrm{~cm}^{-1}$.

Ascorbate Peroxidase (APX) (EC1.11.1.1) Activity: APX activity was determined according to the method of Nakano and Asada (1981). The reaction mixture (total volume $1.5 \mathrm{ml}$ ) contained $50 \mathrm{mM}$ phosphate buffer $(\mathrm{pH}$ 6.0), $0.1 \mu \mathrm{M}$ EDTA, $0.5 \mathrm{mM}$ ascorbate, $1.0 \mathrm{mM} \mathrm{H}_{2} \mathrm{O}_{2}$ and $50 \mu \mathrm{L}$ enzyme extract. The reaction was started by the addition of $\mathrm{H}_{2} \mathrm{O}_{2}$ and ascorbate oxidation was measured at 290nm for about one min. Enzyme activity was quantified using the molar extension coefficient for ascorbate $\left(2.8 \mathrm{mM}^{-1}\right)$ and the results were expressed in $\mu \mathrm{mol}$ $\mathrm{H}_{2} \mathrm{O}_{2}{ }^{\mathrm{g}-1} \mathrm{~F}$.W, taking in to consideration that $2 \mathrm{~mol}$ ascorbate was required for reduction of one $\mathrm{mol}_{2} \mathrm{H}_{2} \mathrm{O}_{2}$.

\section{Determination of Protein}

Total nitrogen was determined in accordance of Kjeldahl (1883). Approximately $0.2 \mathrm{gm}$ of the sample containing protein was weighted out, making a note of the weight, and placing the sample into a digestion flask, along with $10 \mathrm{ml}$ of concentrated sulfuric acid $\left(\mathrm{H}_{2} \mathrm{SO}_{4}\right)$. Seven grams of potassium sulfate and a catalyst, usually copper was added. The digestion tube/flask and mixture was brought to a "rolling boil" (about $370^{\circ} \mathrm{C}$ to $400^{\circ} \mathrm{C}$ ) using a heating a block. The nitrogen content is then estimated by titration of the ammonium borate formed with standard sulfuric or hydrochloric acid, using a suitable indicator to determine the end-point of the reaction.

\section{Catalase}

\section{Results}

Our results showed that enzyme activities of CAT, increased significantly (1\% level) in all cultivars (Fig.1) under salt stress conditions over their controls. However, BARI Mung6 showed much more elevated $(0.540 \mathrm{mM} / \mathrm{ml})$ levels of CAT then others. CAT activity was gradually decreased by the application of chitosan with or without salinity for all genotypes. The lowest $(0.125 \mathrm{mM} / \mathrm{ml})$ CAT accumulation was also found in BARI Mung6 under chitosan induced condition. 


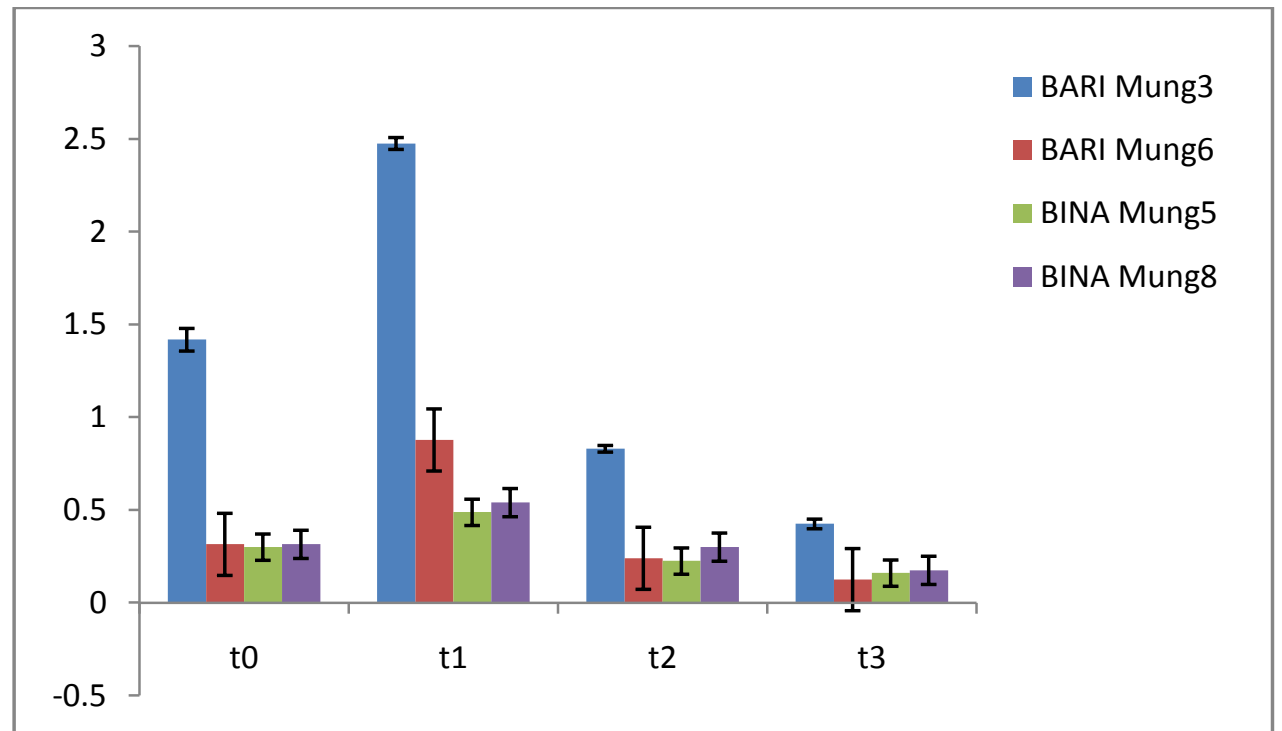

Figure 1: Catalase activity in four varieties under different treatments viz. $t_{0}=$ control, $t_{1}=$ salinity, $\mathrm{t}_{2}=$ salinity+chitosan, $\mathrm{t}_{3}=$ chitosan.

\section{Peroxidase'}

The peroxidase activity showed a similar increasing trend as that of CAT. The highest $(0.406 \mathrm{mM} / \mathrm{ml})$ activity was recorded in BARI Mung6 under salinity. Increased peroxidase activity indicated the formation of large amount of $\mathrm{H}_{2} \mathrm{O}_{2}$ which could release enzyme from membrane structure. However, POD activity was expectedly decreased by chitosan application in saline and control condition. Chitosan alone significantly decreased POD level even than the control $(0.082 \mathrm{mM} / \mathrm{ml})$ in BINA Mung5 which was lowest value of POD accumulation in this study.

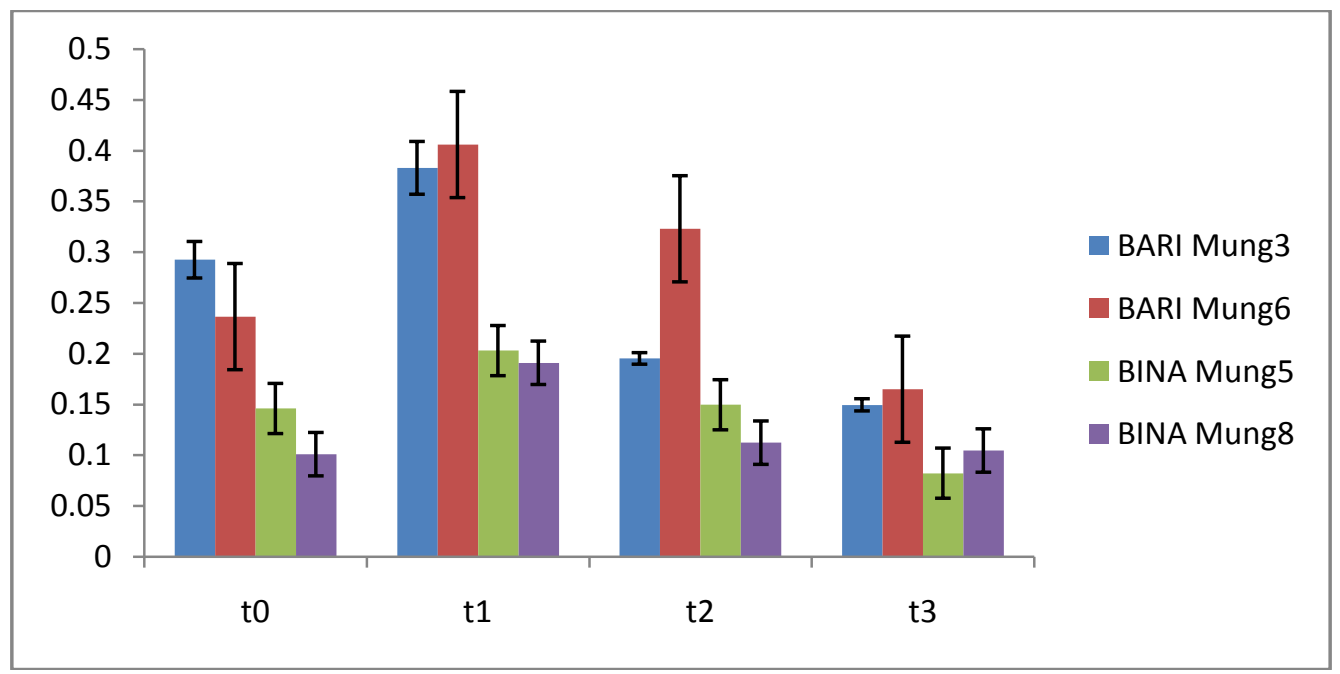

Figure 2: POD activity in four mungbean varieties under different Treatments viz. $t_{0}=c o n t r o l, t_{1}=$ salinity, $\mathrm{t}_{2}=$ salinity+chitosan, $\mathrm{t}_{3}=$ chitosan.

\section{Ascorbate Peroxidase activity}

In our study the highest APX activity was recorded as $11.99 \mathrm{mM} / \mathrm{ml}$ in BINA Mung8 under salinity which was significantly (1\% level) different than the control. APX activity was decreased significantly during interaction between salinity and chitosan in all varieties. Lower level of APX activity was recorded $(3.99 \mathrm{mM} / \mathrm{ml})$ in BINA Mung5 in chitosan applied condition which was significantly lower than salinity with chitosan application and also to the control.

The data indicated that the plants were subjected to salt induced oxidative stress. However, chitosan exhibited positive effects on salt stress alleviation through the reduction of enzyme activity in all varieties. 


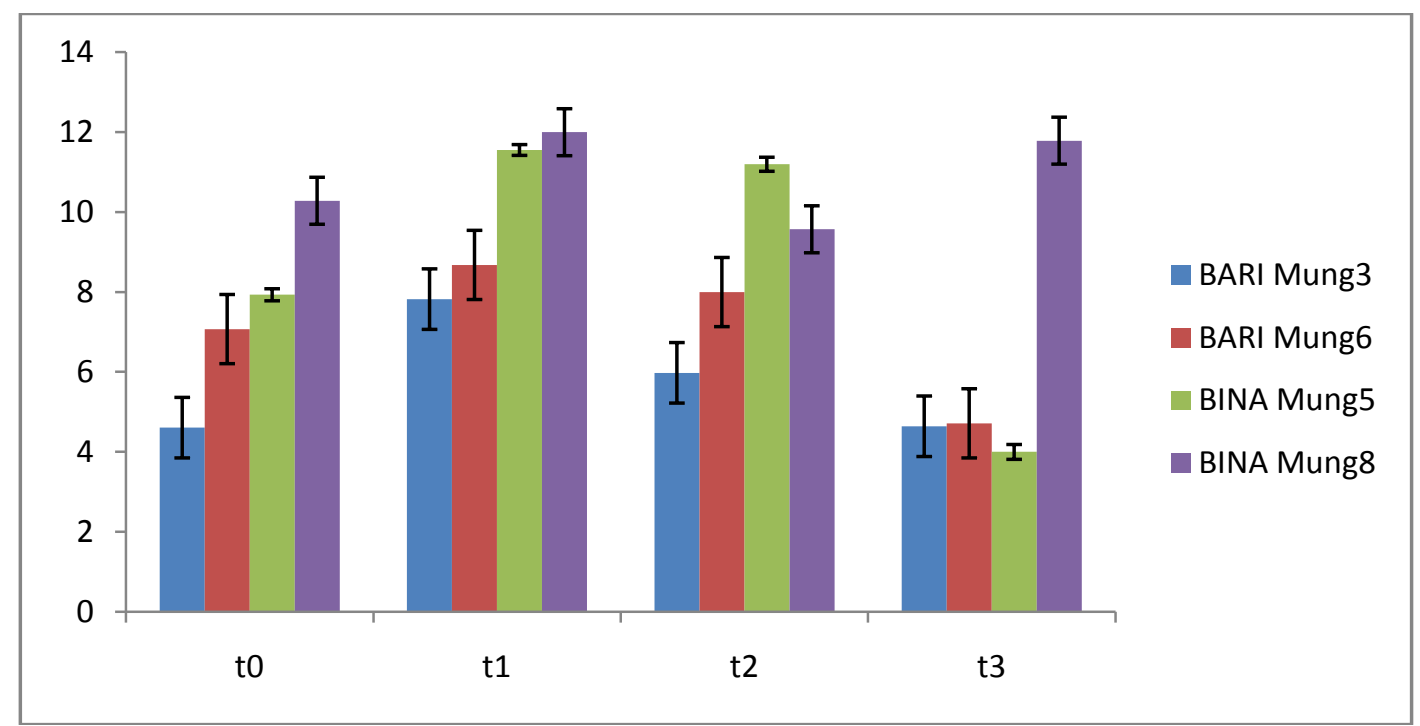

Figure 3: APX activity in four mungbean varieties under different treatments viz. $\mathrm{t}_{0}=$ control, $\mathrm{t}_{1}=$ salinity, $\mathrm{t}_{2}=$ salinity+chitosan, $\mathrm{t}_{3}=$ chitosan.

\section{Protein (\%)}

Changes in the protein content in the mungbean seed in response to $\mathrm{NaCl}$ and chitosan are given in Fig.4. In the present study, soluble protein content was greatly reduced under salinity in all varieties over their respective control ones. The lowest value of protein content was found $17.135 \%$ in BINA Mung5 under salinity. Interaction between salinity and chitosan overcame this limitation of lower protein content significantly in all varieties. Maximum protein content was found 23.99\% in BINA Mung8 under chitosan treated condition which is not significantly different than the control.

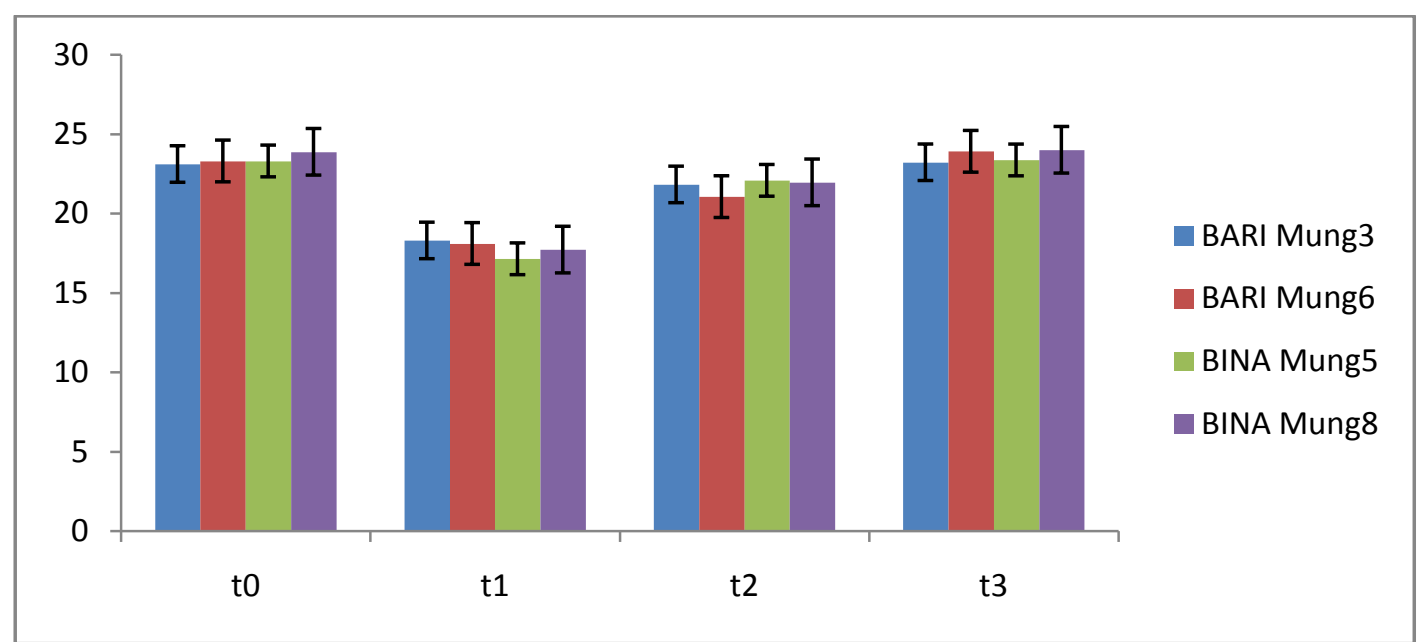

Fig 4. Protein content in four mungbean varieties under different treatments viz. $\mathrm{t}_{0}=$ control, $\mathrm{t}_{1}=$ salinity, $\mathrm{t}_{2}=$ salinity+chitosan, $\mathrm{t}_{3}=$ chitosan.

\section{Antioxidant enzymes}

\section{Discussion}

Abiotic stress like salinity affects plant physiological and biochemical processes which lead to the formation of ROS. Elevated ROS stages could cause oxidative damage to membrane lipids, proteins and nucleic acids. To control the levels of ROS and protect the cells from injury under stress conditions, it is important to scavenge ROS. CAT as well as POD and APX (Passardi et al., 2005) are considered as useful enzymes that help plants to defend salt stress through suppressing ROS.

As expected, in the current study, the activities of CAT, POD, and APX increased under salt stress. However, chitosan induction showed reduced antioxidant enzyme activity compare to their salt stress condition.

Willekens et al. (1997) suggested that the function of CAT in the cell could remove the bulk of $\mathrm{H}_{2} \mathrm{O}_{2}$ where as POD would be involved mainly in scavenging $\mathrm{H}_{2} \mathrm{O}_{2}$, that is not taken by CAT. POD and APX are widely distributed in higher plants where they are involved in various processes including lignifications, auxin 
metabolism, salt tolerance and heavy metal stress (Passardi et al., 2005). They proposed that POD and APX were the scavenging enzyme to remove the toxic oxygen radicals from the cells. Moreover, the increased POD and APX activity were available mainly due to increased enzyme synthesis and might be useful for adaptation under conditions requiring prevention of peroxidation of membrane lipids.

The reduced antioxidant enzyme activity due to chitosan application might be caused by the superoxide scavenging ability provided by low concentration of chitosan. Since, antioxidants play an important role in preventing stress induced accumulation of toxic concentrations of ROS. Nusrat and Rafiq (2012) proposed that enhanced resistance to oxidative stress in plants could be achieved by the antioxidant properties of chitosan.

\section{Protein}

In legumes, as a major constituent, protein enriches the quality of the food stuff. However, in present research work salinity showed reduced protein content in all varieties. Such trend is similar in accordance with the finding by Joshi and Misra (2000), where they proposed the declined protein content was responsible because of proteolysis and decreased protein synthesis. Meanwhile, the foliar application of chitosan enhanced the protein content in saline condition in all varieties. The stimulating effect of chitosan on protein accumulation could be attributed through a combination of complex processes:

- Water and nutrient uptake by adjusting cell osmotic pressure (Sunil et al., 2012).

- Less ROS accumulation by increasing antioxidants and enzyme activity (Guan et al., 2009).

- Biosynthesis and translocation of secondary metabolites (Farouk and Amany, 2012).

\section{Conclusion}

It is approved that chitosan can stimulate physiological processes; improve vegetative growth by adjusting cell osmotic pressure. Moreover, biosynthesis and active translocation of secondary metabolites could have positive role on increased biomass production. Chitosan application showed reduction of such enzyme activities even in saline condition. It was observed previously that low concentration of chitosan could scavenge superoxide. Such antioxidant properties of chitosan could enhance resistance to oxidative stress i.e. ROS in plants. Hence chitosan could reduce the activities of CAT, POD and APX as well as enhance protein content in the long run. Therefore, it can be concluded from the results that chitosan, an effective bio-stimulator to enhance plant growth, yield and plant tolerance to oxidative stress under salinity, could overcome severe stress through the reduction of enzyme activity caused by scavenging of ROS.

\section{References}

[1]. Arbona, V. and C.A. Gomez (2008). Antioxidant Enzymatic Activity is Linked to Salt Stress Tolerance in Citrus. Plant Physiology 132: $452-466$.

[2]. Apel, K. and H. Hirt (2004). Reactive oxygen species: Metabolism, Oxidative Stress, and Signal Transduction. Annu Rev Plant Biology 55: 373-99.

[3]. Anjum, A. (2012). Comparative Studies on Antioxidant Enzyme Action and Ion Accumulation in Soybean Cultivars under Salinity Stress. Environ. Biol. 33: ISSN: 0254-8704.

[4]. Ashraf, M. and M. Shahbaz (2012). Growth Stage Based Modulation in Antioxidant Defense System and Proline Accumulation in Two Hexaploid Wheat (Triticum aestivum L.) Cultivars Differing in Salinity Tolerance. Flora. 207: 388-397.

[5]. Anjaneyulu, E. and M. Balaji (2013). Effect of Salinity Stress on Antioxidant Defense System of Two Finger Millet Cultivars (Eleusine coracana (L.) Gaertn) Differing in Their Sensitivity. Advances in Biological Research 7(5): 180-187.

[6]. Aebi, H. (1984). Catalase in vitro. Methods Enzymol.105: 121-126.

[7]. Chakrabarti, N. and S. Mukherji (2003). Effect of Phytohormone Pretreatment on Nitrogen Metabolism in Vigna radiate under Salt Stress. Biol. Plant. 46: 63-66.

[8]. Dzung, N.A., K. Phuong and T.T. Dzung (2011). Research on Impact of Chitosan Oligomers on Biophysical Characteristics, Growth, Development and Drought Resistance of Coffee. Carbohydrate Polymer. 84: 751-755.

[9]. Farouk, S. and R. Amany (2012). Improving Growth and Yield of Cowpea by Foliar Application of Chitosan under Water Stress. Egypt. J. Biol. 14: 15-27.

[10]. Gao, J.P., C. Dai-Yin and H. Lin (2007). Understanding Abiotic Stress Tolerance Mechanisms: Recent studies on stress response in rice. J. Integrate. Plant Biol. 49: 742-750.

[11]. Guan, Y.J., H. Jin, X. Wang and C. Shao (2009). Seed Priming with Chitosan Improves Maize Germination and Seedling Growth in Relation to Physiological Changes under Low Temperature Stress. Journal of Zhejiang University Science B. 10(6): 427-433.

[12]. Joshi, A.J., A. Sagar, H. Heriglajia (2002). Effect of Seawater on Germination, Growth, Accumulation of Organic Components and Inorganic Ions in Halophytic Grass, Heleochola setulosa (TRIN). Blattet McCann Indian J. Plant Physiol. 7: 26-30.

[13]. Kjeldahl, J. (1883). A New Method for the Determination of Nitrogen in Organic Bodies. Analytical Chemistry. 22: 366.

[14]. Khan, M.H., K.L. Singha and S.K. Panda (2002). Changes in Antioxidant Levels in Oryza sativa L. Roots Subjected to NaCl Salinity Stress. Acta Physiol. Plantarum. 24: 145-148.

[15]. Koskeroglu, S. and T.A. Levent (2008). The Investigation on Growth and Some Antioxidative Enzymes of the Maize (Zea mays L.) Plant under Salt and Water Stress. International Meeting on Soil Fertility Land Management and Agroclimatology. Turkey, pp. 76577.

[16]. Kumar, K.B. and P.A. Khan (1982). Peroxidase and Polyphenol Oxidase in Excised Ragi (Elaucine coracona cv. 2020 Leaves During Senescence. Indian J. Expt. Botany. 20: 412-416.

[17]. Mittova, V., M. Tal and G.M. Volokita (2002). Salt Stress Induces Up-regulation of an Efficient Chloroplast Antioxidant System in the Salt-Tolerant Wild Tomato Species Lycopersicon pennellii but not in the Cultivated Species. Physiol. Plant. 115: 393-400. 
[18]. Moftah, A.H. and B.E. Michel (1987). The Effect of Sodium Chloride on Solute Potential and Proline Accumulation in Soybean Leaves. Plant Physiol. 83: 238-240.

[19]. Mohammadkhani, N. and R. Heidari (2008). Effects of Drought Stress on Soluble Proteins in Two Maize Varieties. Turk. J. Biol. 32: 23-30.

[20]. Nakano, Y. and K. Asada (1981). Hydrogen Peroxide is Scavenged by Ascorbate-Specific Peroxidases in Spinach Chloroplasts. Plant Cell Physiol. 22: 867-880.

[21]. Nusrat, J and R. Ahmad (2012). The Activity of Antioxidant Enzymes in Response to Salt Stress in Safflower (Carthamus tinctorius L.) and Sunflower (Helianthus annuus L.) Seedlings Raised from Seed Treated with Chitosan. Journal of the Science of Food and Agriculture. 93(7):1699-1705.

[22]. Park, P.J. and S.K. Kim (2004). Free radical scavenging activities of differently deacetylated chitosans using an ESR spectrometer. Carbohydr. Polym. 55: 17-22.

[23]. Passardi, F., C. Cosio, C. Penel and C. Dunand (2005). Peroxidases Have More Functions than a Swiss Army Knife. Plant Cell Rep. 24: $255-265$

[24]. Ruan, S.L. and Q.Z. Xue (2002). Effects of Chitosan Coating on Seed Germination and Salt Tolerance of Seedlings in Hybrid rice (Oryza sativa L.). Acta. Agronomica Sinica. 28(6): 803-808

[25]. Venkatesan, A. and S. Sridevi (2009). Response of Antioxidant Metabolism to NaCl Stress in the Halophyte Salicornia Brachiata roxb. J. Phytology. 4: 242-248.

[26]. Willekens, H., D. Inze, M.V. Montagu and W Van (1995). Catalases in Plants. Mol. Breed. 1: $207-228$.

[27]. Yasar, F., S. Ellialtioglu and K. Yildiz (2008). Effect of Salt Stress on Antioxidant Defence Systems, Lipid Peroxidation, and Chlorophyll Content in Green Bean. Russ. J. Plant Physiol. 55: 782-786.

[28]. Yasin, M., R. Zada and B.H. Niazi. 1998. Effectiveness of chemical and biotic methods for reclamation of saline-sodic soil. Pak. J. Soil Sci., 15: 179-182. 